Article

\title{
Caught in between: Profanation and Re-Sacralization in Marco Bellocchio's Nel nome del padre (1971)
}

\author{
Silvia Angeli \\ School of Media Arts and Design, University of Westminster, Watford Road, Northwick Park, \\ Middlesex HA1 3TP, UK; S.Angeli1@westminster.ac.uk
}

Received: 23 July 2018; Accepted: 23 August 2018; Published: 24 August 2018

\begin{abstract}
This article assesses the coexistence of the practices of profanation and re-sacralization in one of Marco Bellocchio's most understudied films: Nel nome del padre (In the Name of the Father, 1971). Indeed, such practices rarely situate themselves at opposite ends of the spectrum but rather are integrated within other works by the same director, and even within the same film. By providing a content and stylistic analysis of episodes of profanation and re-sacralization, this article highlights how Bellocchio profanes traditional Roman Catholic elements through the employment of parody and satire as well as how he re-sacralizes unorthodox characters and situations using narrative, symbolism, and iconography. This integration allows him to deliver his criticism of pre-conciliar Roman Catholicism (its folk manifestations at grassroots level, empty rituals, and sexuophobic education), on the one hand, and identify possible alternatives, characterized by a more progressive, tolerant, and forgiving religious sentiment, on the other. What emerges is Bellocchio's essentially ambivalent attitude toward religion, characterized by the simultaneous and apparently contradictory need for both more and less Catholicism.
\end{abstract}

Keywords: Italian cinema; Roman Catholicism; religion and film; Marco Bellocchio; Nel nome del padre (1971)

\section{Introduction}

The BFI Southbank recently dedicated a retrospective to the work of Marco Bellocchio titled, "Satire and Morality: The Cinema of Marco Bellocchio" - a title that highlights the two extremes between which the work of the Italian director has oscillated throughout his career. Bellocchio is a self-professed atheist ${ }^{1}$ who has nevertheless engaged with Roman Catholicism (henceforth "Catholicism") in all his film-making. As Brook puts it, "What is intriguing about Bellocchio's films is not so much their manifest attack on Catholicism across five decades of filmmaking but-reading against the surface of the films-the peculiar and continuing lure of the church" (Brook 2013, p. 399). While it would be tempting to ascribe the director's animosity toward the Roman Catholic Church (henceforth "Catholic Church") to the strict education he received in his family and at the Catholic boarding schools he attended (Bellocchio and Fofi 1971), this would also be extremely reductive. In fact, Bellocchio's issues with Catholicism exceed his childhood experiences and situate themselves in the wider context of questions about personal freedom and self-determination. In a vision clearly reminiscent of Althusser (2008) concept of ideological state apparatuses, Bellocchio identifies the Catholic Church as yet another controlling and interfering institutional power alongside the family and educational system. It is certainly no coincidence that in his early films, he violently attacks the

1 Bellocchio has frequently defined himself as an atheist. On other occasions, he has preferred the term "agnostico" ("agnostic") or "laico" ("laic"). For more information, see Morgoglione (2006). 
family and bourgeois life of provincial towns in the north of Italy in I pugni in tasca (Fists in the Pocket, 1965) and La Cina è vicina (China is Near, 1967), asylums in Matti da slegare (Fit to Be Untied, 1974), and even the army in Marcia trionfale (Victory March, 1976). For the same reasons, some of his most recent works such as L'ora di religione (My Mother's Smile, 2002), Bella Addormentata (Sleeping Beauty, 2012), and Sangue del mio sangue (Blood of My Blood, 2015) have sharply criticized Catholicism, too.

This critical disposition, however, does not prevent Bellocchio from drawing on the immense repertoire of traditional Catholic themes and symbolism for his work. Fantuzzi $(2005$, p. 71) points out that Bellocchio's cinematic ouvre is characterized by a constant oscillation between the two dimensions of "sacrality" ("sacralità") and "desecration" ("dissacrazione"). This tension relies on what Fantuzzi calls "a double negation," explaining that the director's "irreverent gesture" aims, first, to reveal the hypocrisy and emptiness hidden behind certain rituals. In this sense, the operation is an "act of denunciation" of the lack of authenticity (Fantuzzi 2005, p. 71). Nowhere does this become clearer than in his 1971 work $^{2}$ Nel nome del padre (In the Name of the Father), the focus of this article. ${ }^{3}$ The film tells the story of Angelo and the impact of his arrival in a strict Catholic boarding school in the school year 1958/1959. Run by lazy, incompetent priests-with the exception of the clever yet extremely disillusioned deputy director, Father Corazza-the institution embodies both pre-conciliar Catholicism and Italian society (Bondanella 2009).

It is possible to identify three broad groups in the film: the priests, who represent the ruling class; the servants, who stand for an exploited and marginalized social class; and the students, who represent the middle class. Angelo immediately assumes the role of the leader, pushing his classmates to question their blind obedience to the establishment. With the help of another student, Franc, he organizes a grotesque and blasphemous play loosely based on Goethe's Faust. After the play, everything precipitates. Fra' Matematicus dies and his body is kidnapped by Angelo, who, in a dog costume, carries it around the school, followed by Father Corazza. The servant Beato, who had been having an affair with one of the boys, shoots himself, leading the servants to finally rebel against the priests. However, both revolts, albeit different in nature, end in failure. While the priests accept some of the servants' requests, they fire Salvatore, their leader; moreover, the students' protest is quashed by their own limited goals and inability to establish an alliance with the servants. The film ends with Angelo and the servant Tino, a man who believes himself to be an alien from the planet Mongo, driving on the highway and discussing politics, power, and technology.

Bellocchio is certainly not the first Italian director to associate unorthodox elements with a traditional Catholic repertoire. The use of Catholic iconography has indeed characterized Italian cinema since its birth. The reasons for such a large deployment of images are connected to the long history of the Catholic presence on the peninsula as well as the literary and painterly repertoire. Sitney explains:

By far the largest pool of such iconographic images has their sources in the painterly tradition of Italy. The conventional visual code of the Church prescribed the representation of Christ and the narrative events of the Gospel, distinguished the saints by metonymic signs (often the instruments of their martyrdom), and symbolised virtues and vices. The churches, civic buildings, monuments and the decorations of even the humblest homes in Italy continue to employ versions of this code. Italian poetry, especially Dante and the Renaissance epics, accumulates a vast treasury of iconographic images. Thus iconographical representation

2 Nel nome del padre was first presented at the New York Film Festival in autumn 1971. The film was then released in Italy in 1972.

3 Catholicism is hardly Bellocchio's only critical target in Nel nome del padre. In tune with the rebellious spirit of its time, the film reveals its polemic charge by targeting a number of issues such as the inconsistency of the motives behind the students' revolt and the perils of an authoritarian and uncompromising attitude, as expressed by Angelo. Nevertheless, in this article, I focus primarily on the director's criticism of the anachronism of Catholic teachings, the morally dubious conduct of the priests, and the superstitious nature of popular Catholicism in Italy. 
so permeates Italian life that it is not surprising to find it central to the native cinema. (Sitney [1995] 2013, p. 13)

We need only consider the vast number of paintings, sculptures, and buildings that illustrate or allude to episodes of the Old and New Testaments. Artists such as Leonardo da Vinci, Michelangelo Buonarroti, Piero della Francesca, Andrea Mantegna, and Michelangelo Merisi da Caravaggio have lent their artistic geniuses to the depiction of religious topics and biblical episodes, leaving to posterity an immense iconographic repertoire from which to draw. However, while this has always been a mark of Italian cinema, it is only in the post-war era that the iconographic repertoire began to be used provocatively. Again, in the words of Sitney:

One of the post-war Italian cinema's primary gestures of opposition to the Church has been in reimagining and parodying its icons. Rossellini, De Sica, and Pasolini, the three filmmakers [... ] who were the most ambivalent about the Church, tend to use its iconography most explicitly. (ibid.)

Films such as Roberto Rossellini's Roma, città aperta (Rome Open City, 1945) and Paisà (1946); Vittorio De Sica's Ladri di Biciclette (The Bicycle Thief, 1948), Miracolo a Milano (Miracle in Milan, 1951), and Umberto D (1952); and Pier Paolo Pasolini's Accattone (1961) and Uccellacci e Uccellini (Hawks and Sparrows, 1966) all refer to traditional Catholic images, but taint them with provocative implications. Sitney continues:

For example, there seems to be a critical consensus that the shot of the dying Communist in Roma, città aperta, with his head bloodied and arms outstretched, invokes Christ on the Cross. A more controversial attribution would be to see in the sign "Partigiano" attached to the floating corpse of Paisà a variation of the cryptogram "INRI" attached to the Cross. The magical dove of Miracolo a Milano is a version of the Holy Ghost, while the brand name of the bicycle in Ladri di biciclette, "Fides," identifies it as a symbolical instrument, much as the labels in medieval paintings identify symbols. (In a later film, Umberto D, De Sica uses the convention of Fides, the dog, as a similar element in his allegorical pattern). (Sitney [1995] 2013, p. 12)

While a large number of Italian directors have indeed drawn images from the immense repertoire of the Catholic iconographic tradition, the first to systematically do so was Pasolini. From his cinematographic debut Accattone (1961) to the subsequent Mamma Roma (1962), La ricotta (Curd Cheese, 1963), Uccellacci e Uccellini (Hawks and Sparrows, 1966), Il vangelo secondo Matteo (The Gospel According to St. Matthew, 1964), and Teorema (Theorem, 1968), the director associates unconventional elements with Catholic motifs. In relation to this, Ryan-Scheutz observes that:

[t]hese Catholic images were always adapted for Pasolini's purpose and delivered a troubling message. Balilla's reversed sign of the cross at the time of Accattone's death or Stracci's crucifixion (caused by gluttony and perceived as a spectacle by bourgeois viewers) shows how the filmmaker tainted conventional Christian rituals in order to express his concept of authenticity vis-à-vis the mass desecration of genuine sub-cultures, both throughout Italy and the neo-capitalist West. (Ryan-Scheutz 2007, pp. 7-8)

Unlike Pasolini's, Bellocchio's position in relation to Catholicism has rarely been characterized as "ambivalent." For instance, Moliterno defines Nel nome del padre as "a fierce and full-frontal attack on the Catholic boarding school system" (Moliterno 2009, p. 27) and Morandini argues that the work of Bellocchio is marked by "direct, savage, and occasionally grotesque critique of institutions" (Morandini 1997, p. 589). Only Fantuzzi (2005) and Brook $(2009,2013)$ acknowledge that behind this venomous denunciation of religion, its people, and its rituals lies instead a deeper fascination with Catholicism. In her aptly titled article "The Spectacle of the Unseen: Marco Bellocchio and Lure of the Catholic Church," Brook states: “Catholicism's iconography provides Bellocchio's cinema with 
a set of images without which his camera would lose its object. His films hint that Catholicism may remain deeply attractive in Italy's cinema, even where this is firmly disavowed" (Brook 2013, p. 399). Similarly, Fantuzzi (2005) senses a deeper meaning underlying Bellocchio's practice of what he calls "desecration" and "sacrality," namely an expression of regret for the loss of true values. Building on these readings, this article argues that Bellocchio does not limit himself to negative criticisms of Catholicism, but that he also suggests possible alternatives to the religious status quo, ultimately outlining a more tolerant and genuine dimension. It also highlights how the Italian director appears to be caught in between his desire for both more and less religion: more religion in the sense of more genuine and heartfelt participation by both ministers and believers; less in the sense of a less invasive, censoring, repressive institutional presence.

The scope of this article is twofold. First, it highlights how, throughout Nel nome del padre, Bellocchio associates the classic Catholic narrative on symbolism and iconography with unorthodox characters and situations with the intent of profaning the former and re-sacralizing the latter. In the interest of clarifying both these practices, it provides three examples for each. Second, it argues that Bellocchio employs this integration as a critical tool to address a number of issues that he views as plaguing Catholicism as well as outlining a possible alternative to this, namely a more tolerant, understanding, and sincere religious dimension.

To address these two points, the article first focuses on four episodes (Pius XII's funeral, Fra' Matematicus's wake, the miraculous pear tree, and Marsilio's vision) that serve to illustrate Bellocchio's practice of profanation and emphasize how they allow the director's criticism to meet his target. In particular, the profanation of Pius XII's funeral allows Bellocchio to uncover the lack of true religious feelings both in the students and in Father Corazza. The second episode (Fra' Matematicus's wake) serves a similar purpose by uncovering the hypocrisy hidden behind the priests' formal adherence to Catholicism. Thirdly, by portraying the veneration of a young girl by her peasant community, Bellocchio addresses the superstitious attitude embedded in the rural world, at the same time attacking Catholic folk expressions. Finally, the portrayal of Marsilio's vision allows the director to criticize the strict, unforgiving dimension of Catholic education.

The article then focuses on two episodes that serve to illustrate Bellocchio's practice of re-sacralization: Muscolo's crucifixion and the servants' dinner. In particular, the linking of Muscolo to Jesus through narrative, symbolic, and iconographical elements highlights the boy's exploitation and suffering at the hands of Angelo. Similarly, the association of the servants with traditional Catholic symbols and iconography during their Christmas dinner allows Bellocchio to underline their oppressed condition.

It might seem bizarre, or even inappropriate, to associate the terms "sacralization" and "desecration" - which clearly belong to a religious sphere and are the prerogative of religious authorities-to a film. Nevertheless, these words are often used by film scholars in a non-literal sense to describe these filmic practices of profanation and sanctification through the association of images with unconventional motifs. ${ }^{4}$ Pasolini himself, however, who had no doubts about the sacred quality of cinema and famously referred to his cinematic style as "technical sacrality" ("sacralità tecnica") (Pasolini 1999a, pp. 2768-69)—rejected the term "desecration," which he considered to be "a petit-bourgeois trend" (Pasolini and Halliday 1992, p. 1336). He spoke instead of "re-sacralization" (ibid.). In an interview with Jean Duflot, he stated: "It is truly against my nature to desecrate either things or people. Instead, I tend to re-sacralize them as much as possible" (Pasolini 1999b, p. 1423). As such a practice can be applied to the work of Bellocchio, I speak of "profanation" and "re-sacralization herein - the latter in the Pasolinian sense of the term. A comparison with the films of Pasolini, which have more frequently been the object of rigorous scholarly investigation, is also offered throughout the article to provide a more exhaustive analysis of Bellocchio's practices of profanation

4 See, among others, the work of Fantuzzi (2005), Subini (2009), and Jacobs (2012). 
and re-sacralization. Throughout, this study thus considers the film's narrative (i.e., story, plot, and characters), with a focus on Catholic themes, as well as its style (from mise-en-scène to cinematography, and from editing to sound), with a focus on Catholic symbolism and iconography. The analysis of these elements in the film reveals how the practices of profanation and re-sacralization are often combined to accomplish an otherwise unobtainable provocative and challenging effect as well as encourage deeper reflection in the audience.

\section{Religion and Film}

The field of religion and film is characterized by a degree of confusion that borders on anarchy. While the relationship between cinema and religion is an old one- to quote the French critic and theorist André Bazin, "cinema has always been interested in God" (Bazin 1997, p. 61)—a systematic approach to its study did not appear until the 1970s. Indeed, there remains little consensus on the most appropriate methods for studying religion and film, and even open skepticism over the academic integrity of such an endeavor.

Traditionally, religion in films has been approached from three perspectives: from a substantial point of view (i.e., the story narrated), from a formal point of view (i.e., the film style), and from a functional point of view. In particular, scholars have studied how religion "functions" in films in two ways. They have considered the values that films encourage as well as their moral impact on viewers, and they have analyzed the degree to which the audience views films as a religious experience. There are, however, a number of issues with these four approaches, which are essentially rooted in the difficulty of determining what constitutes religion in a film. It is obviously quite different to claim that a film deals with religious topics or is religious insofar as it instigates religious feelings in the audience-be it for its themes, its particular style, its implicit or explicit ethics, or the supposedly striking similarities that link the rituals of mass and cinema going. The problem indeed lies not only in universalizing an incredibly subjective experience but also in erasing any cultural, religious, and social differences among countries and even within the countries themselves.

The impossibility of coming up with an all-encompassing permanent definition has been pointed out by critics such as Wright, who observes that "a consideration of a film's religious qualities, like that of its meanings more generally, is not something that an individual critic can determine once and for all" (Wright 2007, p. 78). This position is echoed by Deacy, who argues that "Nobody functions in a cultural vacuum, and there is no such thing as a definitive, normative or objective theological lens through which one may embark upon a theological conversation" (Deacy 2008, p. 2). In agreement with Deacy as well as Wright, I reject the idea that religion in film can be identified by a universal formula, valid for any country and time. Similarly, I also reject the notions that it coincides with a supposedly "mystical" experience or with an encounter with the "sacred," that such an encounter is linked to the presence of a particular style, that it awakens religious feelings in the viewer, and that the audience is therefore able to assimilate the experience of film watching and churchgoing. In fact, these elements rest on parameters characterized by a high degree of subjectivity and variability and, as such, hardly constitute an appropriate scale with which to measure the presence of religion in film.

What I suggest instead is the analysis of the presence of the elements of a particular religious tradition-in this case, Catholicism. Films might indeed offer a reinterpretation of episodes of the Scriptures, such as passions, last suppers, depositions, and nativities, as well as representations of Catholic rituals (mass, burials, and communions). In addition, they present Christ-like figures and saints as well as other religious elements such as the supernatural (angels and miracles). Moreover, they convey Catholic elements through direct quotes from the Scriptures and from elements of "Catholic Social Doctrine" such as the principle of solidarity and the preferred option for the poor and vulnerable. Finally, they also consist of constant references to symbols (the cross, the sacred book, and stigmata) as well as paintings of the Catholic iconographical repertoire. The presence of these elements will be shown through examples from Nel nome del padre. 


\section{Examples of Profanation}

\subsection{Pius XII's Funeral}

The first example selected to illustrate Bellocchio's practice of the profanation of traditional Catholic elements is the inclusion of the television broadcast of Pope Pius XII's funeral in the school's common room. The students react to the news with not only a lack of reverence but also total and utter indifference. Absorbed in their matches of ping pong and pool, they completely ignore the news of the pontiff's death. The fact that two of them actually start a fight because they lost the game only serves to highlight how little consideration they hold for the school's religious tradition. This sense of indifference is heightened by the attitude of Father Corazza, who is following the ceremony only distractedly while smoking a cigarette. Indeed, according to the Magisterium, smoking is actually an actus indifferens: an "indifferent act." While not an inherently negative action-actions in themselves are neither good nor evil (Marenbon 1997), and only the abuse of this vice constitutes a mortal sin-the image of a smoking priest can arouse a feeling of indignation in viewers (Betti 2010). Finally, the juxtaposition of the gravity of the commentator's voiceover and solemnity of the music score on the television, on the one hand, and the sound of the ping pong ball bouncing on the table, on the other, also contributes to creating a sharp contrast.

While Bellocchio's films often feature the presence of reactionary popes (Aprà 2005), such as Paul VI in Sogni infranti (Broken Dreams, 1995) and Pius XII in La religione della storia (History's Religion, 1998), the broadcast of the latter's funeral is extremely significant here. Pius XII (1938-1958), born Eugenio Pacelli, is in fact a rather controversial figure in Italian history. While he was rarely criticized in life and actually appeared to be an extremely beloved pope, within 15 years of his death, he became the target of much criticism. His detractors accused him of morally dubious conduct before, during, and after the Second World War, particularly not speaking out against the Holocaust with sufficient firmness and clarity. ${ }^{5}$ However, what has become known as "the problem of the silence of Pius XII" (O'Malley 2010, p. 282) is hardly the only reason behind his criticism. Indeed, not only did the pontiff have a rather intransigent position on the topics of abortion and contraception as well as "an almost puritanical approach to the questions of sex" (Pollard 2014, p. 458), but he also held a strict attitude toward Italian communism and famously issued a decree in which he officialized the excommunication of Catholics affiliated with communist organizations (Ginsborg 1990). Another reason for such criticism was his friendly relationships and the accords reached with the dictatorial regimes of Antonio Salazar's Portugal and General Francisco Franco's Spain (Pollard 2014). It follows that Pius XII had become, especially at the time of the film's release, "a symbol to leftists in Italy of the Vatican's reactionary politics" (Bondanella 2009, p. 249).

The use of archival footage both underlines the anachronistic role played by the Catholic Church and signals how the particular reactionary form of Catholicism embodied both by the Pope and the boarding school was about to be discarded. By juxtaposing the images of the papal funeral with something as trivial as a ping pong match, and by pointing out how the students and deputy director care more about the latter than the Pope's passing, Bellocchio highlights not only the gap between official Catholicism and the daily lives of the Italian populace but also the latter's lack of true religious sentiment.

5 Sparked by the publication of Rolf Huchhuth's play "Der Stellvertrer" (The Deputy") in 1963 and reignited in 1999 by the publication of John Cornwell's book Hitler's Pope: The Secret History of Pius XII, this controversy shows no sign of abating (Sànchez 2002; Pollard 2014). While over the years many of these accusations have been refuted and more balanced accounts of the topic produced (Sànchez 2002), one should not forget that Nel nome del padre was released in 1971, that is during the aftermath of the publication of Huchhuth's work. 


\subsection{Fra' Matematicus's Wake}

The second episode under focus is the kidnapping of Fra' Matematicus's corpse by Angelo. After the friar's death, according to tradition, the school holds a wake for the deceased, placing his body in a room where his brothers can pray and recite the rosary. The priests, however, soon fall asleep. When Angelo lifts Matematicus's body, they do not wake or even stir. In an almost comic turn of events, one of them actually ends up falling into the empty coffin without waking up. When the priest is eventually shaken awake by an angry Father Corazza demanding to know where their dead brother is, he excitedly exclaims, "He has resurrected!" Angelo carries the body throughout the school before finally returning it.

Interestingly, during this sequence, Angelo is wearing a dog costume, which he had previously used in the school play, a spoof of Goethe's Faust. While this is obviously to avoid being recognized, there is also a deeper, symbolic meaning. In fact, the dog is "an ambiguous animal symbol in Christian art denoting either fidelity or evil" (Apostolos-Cappadona 1994, p. 107). While the dog, as the first known domesticated animal, is often associated with positive feelings such as loyalty, altruism, and generosity, dogs are also connected with the idea of night and death and, as such, they are often seen as "an omen of doom" (Sax 2001, p. 87). Moreover, the dog often assumes the role of the psychopomp, the figure who guides and escorts souls in the afterlife (Sax 2001, pp. 86-87). Further, the ambivalence of the values associated with the dog has been famously discussed by Erwin Panofsky in relation to Jan van Eyck's Arnolifini Portrait. The little dog at the couple's feet has variously been interpreted as a symbol of fidelity (Carroll 1993) or a reminder of the couple's powerful status (Harbison 1990).

In his seminal essay from 1934, Panofsky acknowledges the abundance of meanings, observing how "iconographical symbols, especially in medieval art, are almost always ambivalent ... Thus, the equation Dog-Faith does not preclude the equation Dog-Animality" (Panofsky 1934, p. 127).

Throughout this sequence, Bellocchio parodies the ideas of death and resurrection, central elements to Catholicism. This profaning operation, which had already appeared in his treatment of Pius XII's funeral, reaches here what is certainly its highest point. The director's parodying and satiric intent becomes especially clear if we consider the interview with Nicoletta Zalaffi in which Bellocchio offered an interesting insight on the role of death in Catholic ideology:

Death represents a fundamental moment in the life of a Catholic, and in whatever form he will always be conscious of it, because it's a stake that is too often at risk. The edifice of death in which a Catholic feels himself sheltered is extremely dangerous because, paradoxical as it may seem, there is nothing more 'tranquillising' than the constant reminders of death, and the mixture of obsession and reassurance they produce. There is nothing more dreadful than to forget that you have to die, and moreover that death will come without warning. (Bellocchio and Zalaffi 1973, p. 199)

Moreover, the sequence once again highlights the hypocrisy hidden behind what is only a formal and superficial adherence to Catholicism. The priests are a bunch of lazy, gullible men who fall asleep instead of watching over their deceased brother. While Angelo's gesture is certainly a gratuitous and unnecessary provocation, Bellocchio takes particular issue with their lack of emotional involvement and participation.

\subsection{The Miraculous Pear Tree}

Bellocchio's parodying and satiric intentions re-emerge in his portrayal of the forms of popular Catholic devotion taking place in the peasant world. During one of the very few scenes set outside the school, Angelo and Franc, on their way to Franc's house for the holidays, drive past a field. In the field, a group of peasants is reciting the rosary, led by a young woman dressed in white. The girl, Lisetta, is said to be able to see and communicate with the Virgin Mary and is thus worshipped by the peasants. As Franc explains to Angelo, such apparitions occur under a "miraculous pear tree" that blossoms in winter. Interestingly, such a privileged channel of communication is used by the girl not to deliver 
important information but rather to relate what she had for lunch. Encouraged by her parents, she tells the Virgin: "I ate pasta. Then steak with salad, then gorgonzola ... " The actions of the main characters throughout the scene are imbued with sarcasm and present a strong critique of such superstitious practices. In fact, Angelo's and Franc's mode of transport, a car, is itself a symbol of progress and industrialization, underlining the separation between the bourgeois and peasant worlds. Further, throughout the sequence, the two remain in the car; they do not get out or roll down the window but limit themselves to critically observing the scene unfolding before their eyes. Moreover, the sarcastic tone is highlighted by the parents' insistence that their daughter describe every meticulous aspect, as if what she had for lunch was somehow of any importance at all. The comic effect is emphasized by both the parents' praise of such an extraordinary act and the girl's own zealousness in describing her lunch in such intricate detail.

It is, however, in a later scene that the film's critical tone becomes especially clear. In this sequence, Angelo is now accompanied by Tino as they once again drive past the field. This time, however, they get out of the car and proceed to cut down the tree. While they are busy in their task, Lisetta awakens and walks toward them. She does not protest, however; indeed, she says nothing. She and Angelo just stare at each other until the tree falls: "Everything that is anti-scientific must be eliminated!" says Angelo. "Now you're free!" he continues, "go work in a factory!" He then turns and walks away, leaving her staring at the fallen tree, which here symbolizes pre-industrial, peasant civilization, soon to be left behind by the industrialization and scientific progress incarnated by Angelo.

When asked about this scene, Bellocchio explained how the tree constituted a pretext for illustrating Angelo's fanaticism and obsession with scientific progress. He stated: "Angelo, who only believes in science, in technology, wants to eradicate any popular form of superstition, religiosity, which might in anyway hinder development" (Bellocchio and Fofi 1971, p. 34). However, the film's criticism does not end there: Angelo's last words to the girl are highly significant, as they uncover another essential element. According to Angelo, now that the pear tree has been cut down, Lisetta is "free". Free, one could argue, means both from her role as an "intermediary" between the Virgin and the faithful as well as, most importantly, from the narrow-minded, superstitious mentality of her community. By suggesting that she "go work in a factory", however, Angelo implies that she will never be free. There, in fact, she will have a new master; she will instead simply develop new beliefs-most likely political ones-that will prove as illusory as her previous ones. According to Angelo's classist view, Lisetta is thus no different from the majority of his schoolmates, teachers, or servants. Incapable of critical thinking, she will never overcome her subordinate status. Ultimately, she will merely swap one form of slavery for another.

Similar to the work of Pasolini, Nel nome del padre critically reflects on the contrast between the modern, industrialized world and the rural world. However, Pasolini suggests a certain authenticity underlying the practices and beliefs of the peasants, which is completely lost on the bourgeoisie (Pasolini 1998, p. 1036; Benini 2015, pp. 143-46), whereas Bellocchio is highly critical of their naïve, superstitious attitude. Far from being portrayed as the last post for those of genuine Catholic faith, the peasant world is depicted as a concentration of false, irrational beliefs. His radical condemnation is further highlighted by his implication of the impossibility of ever freeing oneself from the shackles of this uncritical disposition, even after having left the rural world behind. Nevertheless, it is clear that folk religion is not the only critical target here, but that Bellocchio also takes issue with Angelo's authoritarian and ruthless attitude. His obsession with efficiency, contempt for the mediocrity and laziness of both his peers and the priests, and single-minded determination to dismantle the religious institution reflect not just a no-nonsense, practical, and intransigent attitude but also a cruel and callous one. This aspect has been picked upon by critics. For instance, Bondanella refers to him as "a true neo-Fascist" (Bondanella 2009, p. 249), Brook sees him as "the new capitalist" (Brook 2009, p. 57), and Bernardi argues that he represents "an apostle of the New World, which is rooted in economy and all its corollaries: efficiency, regularity, practicality, productivity" (Bernardi 1978, p. 72). Certainly, Bellocchio's ambivalence toward religion emerges at its clearest in this episode. If, on the one hand, 
the director mocks these superstitious expressions of popular folklore, on the other he condemns Angelo's intolerant behavior toward them. Hence, although in different ways and to different ends, the peasants and Angelo are both excessively fanatical and zealous in their pursuits. The director seems to suggest here that an abundance of religious feelings and devotion, when grounded in false and irrational beliefs, is just as dangerous as its complete absence.

\subsection{Marsilio's Vision}

Finally, the fourth and last moment of profanation considered in this article takes place in the school chapel. The students are sitting and listening, rather distractedly, to the words of Father Granita-interestingly, the word "granita" in Italian recalls "granite" and as such certainly highlights the priest's intransigence-offer an "exemplum," a story in which the protagonist, thanks to morally good or bad behavior, obtains either salvation or damnation of the soul. A literary genre popular in the Middle Ages, the exemplum was used as a means of Christianization or a fight against heresy (Lyons 1989). Here, the story is about a boy of 17-which, significantly, is roughly the age of the protagonists of the film-who falls into temptation, repeatedly commits the sin of masturbating, and subsequently dies a long, painful death. Interestingly, the boy's death is presented as the natural and logical consequence of his moral and physical degradation. Unsurprisingly, masturbation is considered by the Catholic Church to be a grave sin, "an intrinsically and gravely disordered action" (CCC II2532), and the priest's intention here is clearly to instill fear and apprehension to have the students avoid the practice, in line with the repressive and sexuophobic education given at the school. One of the boys, Marsilio, seems to be especially stricken by the story. Next to the priest is a statue, the Our Lady of Sorrows, also known in Latin as Mater Dolorosa, recognizable from an iconographic point of view for having her red heart pierced by seven daggers (Kroger and Granziera 2012). As the priest continues to describe in detail the moral degradation and suffering of the protagonist of the story, Marsilio begins to touch himself. As he does so, the statue comes alive. She walks over to him, but instead of being horrified at what he is doing, she caresses his face and hugs him. However, the sequence hardly terminates on a positive note: the last shot shows a crying, guilt-ridden Marsilio contemplating a skull painted on the wall, acting as a reminder of the gravity of his sins.

Curiously, there has been little elaboration on this scene, one of the most audacious ever attempted in Italian cinema, not only for its juxtaposition of sex with the sacred-which is not completely foreign to Catholicism (Pelaja and Scaraffia 2008)—but also for the implications that it carries. In fact, rather than an actual miracle-Marsilio, after all, is the only one who witnesses the statue coming to life-the sequence most likely belongs to the realm of the "oneiric" (Brook 2007). If the whole sequence is Marsilio's dream or hallucination or a figment of his imagination, the Virgin's behavior is also a product of his mind. It is not uncommon for Catholics to privilege their own "version" of Mary and the saints to the point that they "have tended to splinter the image of Mary to a range of personalities, each of which has become the object of an extensive cult ... [and] each of these Marys has her own iconography in her own set of prayers" (Carroll 1992, p. 2). However, Marsilio's Mary is certainly unique, being compassionate, forgiving, and even maternal, and she does not berate the boy for what he is doing, nor does she judge him, but instead offers him comfort. Her attitude contrasts sharply with that of the priest's macabre, in-depth description of the fate that awaits those who fall into temptation.

In her book La Madonna, Italian anthropologist Magli (1987) considers the cultural construction of Mary and the psychological and emotional investment Italian men have made in her. She argues that over the centuries, popes, theologians, mystics, poets, and artists have turned Mary into the expression of one of the greatest desires of Western culture: a woman who is both a virgin and a mother, who is the daughter of her son, who was conceived without sin and who does not know sexuality, who is an ardently desired bride but, at the same time, remains intangible. In short, she is a woman who ultimately is the complete antithesis to female identity and reality. It is no wonder then that to Marsilio, she is both mother and trusted companion. The boy does not begin masturbating because of her; it is rather the thrill of doing so in the chapel, of transgressing the Catholic norm, and of challenging the 
priest's words. However, he also does not stop masturbating because of her. She does not inhibit him, nor does she censor him. Nevertheless, after consoling him, she returns to her place behind the altar, resuming her hieratic stance and leaving Marsilio prey to his guilt.

Quite understandably, this sequence has caused the most scandal. It is indeed this scene that the Italian censor board mentions when explaining why the film was rated "VM18," which is "forbidden to children under 18" (Italia Taglia 2018). Bellocchio's intention here is hardly to sanctify masturbation. This sequence highlights instead the director's criticism of the school's repressive and sexuophobic attitude. The boarding school is a repressive environment that fosters the spread of both Catholic and middle-class values; in other words, it is the perfect embodiment of Althusser's ideological state apparatuses. Through cultural conditioning, the school aims to harness, if not even change, the nature and sensitivity of the students, mortifying them in their intellectual, physical, and sexual development. At the same time, however, the director contrasts this notion by providing an example of an understanding, sympathetic, and forgiving attitude with his portrayal of the Virgin Mary. In relation to this, it is interesting to note that, originally, Bellocchio had intended to depict the Virgin as a decrepit, sinister-looking woman, as the preparatory sketches in the screenplay indicate (Bellocchio and Fofi 1971). The fact that the director eventually opted for a benevolent, reassuring figure further serves to illustrate his desire to avoid tainting Marsilio's forgiveness and consolation with any negative connotation.

After having outlined how the director profanes traditional Catholic elements, the next section of the article focuses on two examples of re-sacralization.

\section{Examples of Re-Sacralization}

Both the examples of re-sacralization considered in this article have at their center characters who are oppressed and exploited, in various fashions and capacities, by those in power: Muscolo, a student bullied by Angelo, and the servants, who are mistreated and abused (and in one case, even sexually abused) by the school priests. As mentioned in the Introduction, the practice of associating unconventional, unorthodox characters with traditional Catholic symbolism is long established in Italian cinema. One only has to think of the many subproletarian protagonists (Accattone, Ettore, and Stracci) that Pasolini has converted into "Christ-type figures" (Ryan-Scheutz 2007, p. 7) in his work by associating them with Catholic rituals, narratives, paintings, and music. In relation to this, Maggi states, "According to Pasolini, the epic journey toward the sacred finds its most significant crossroad in the places inhabited by the poor, the oppressed, those who live outside the 'conformity' of our capitalistic society" (Maggi 2009, p. 43). In a way, this is exactly what Bellocchio does: he provides a theological justification for their suffering, he returns to these characters their dignity by linking them to religious motifs, and he repositions the marginalized at the very center of the screen.

\subsection{Muscolo's Crucifixion}

Here, Bellocchio draws an analogy between Jesus and one of the students, Muscolo, by using Catholic symbolism and iconography as well as the narrative of the crucifixion, effectively turning the boy into a Christ-like figure. Muscolo bets his peers that he can suspend himself from the rings in the gym for a whole hour. While the other students barely acknowledge him, Angelo takes the bet. This exchange is followed by an apparently unrelated sequence: a nun approaches one of the boys and asks him to help her kill a chicken. The boy, unperturbed, proceeds to break the animal's neck with an ease that suggests a strong familiarity with the practice. His callousness is accentuated by the shot composition: the boy is framed by the horrified nun on the left and by a statue of the Virgin Mary on the right, both conveying a feeling of innocence in the face of such a display of brutality.

This episode, already significant in itself, becomes even more important in its symbolic allusion to the following scenes. The next shots alternate close-ups of the boy suspended from the rings-sweat pouring down his neck, face screwed up in concentration -with wider camera angles. It is here that the Christic analogy becomes clear. First, Muscolo is in a "cruciform pose," one of the marks of the 
cinematic Christ-figure (Kozlovich 2004, §17). Further, the analogy is reinforced iconographically: behind the boy is a large fresco portraying the crucifixion. These visual nods resonate at a narrative level as well. Just when an hour is about to pass, the boy, exhausted, lets go of the rings and falls to the floor, effectively losing the bet. The use of an extremely melancholic flute and harpsichord musical theme (Calabrò 2004) further amplifies the sense of sacrifice and loss in the sequence; the next scene sees Muscolo admitting defeat to Angelo, who then refuses to give him any money in yet another display of callousness and cruelty.

This sequence clearly recalls Pasolini's crucifixion of his subproletarian protagonist in La ricotta (1963). Stracci, a starving extra who plays one of the two thieves crucified with Jesus, dies on the cross for indigestion. The link between the man and Jesus, or rather Pasolini's "re-sacralization" of Stracci, has been noted by many scholars and prompted Benini to conclude that "the homo sacer is the subproletarian flesh" (Benini 2015, p. 58). As Rohdie observes: "There is a social message here: Stracci is the victim of the world which looks on at him, has impoverished him, has made him a non-entity" (Rohdie 1995, p. 112). Much like in Pasolini's works, there is something potentially blasphemous about linking a boy such as Muscolo to Jesus. He is not particularly bright or brave; even his arguably greatest asset, namely his strength ("muscolo" in Italian means "muscle"), turns out to be less than impressive. The same could be said for suggesting that something as trivial as a schoolboy's bet could relate to the crucifixion. However, I believe that Bellocchio's intention is not to suggest an identification in terms of qualities and attributes but rather to focus on the gratuitous suffering as well as the injustices one can experience at the hands of those in power.

\subsection{The Servants' Dinner}

A similar intent is behind the next moment, which focuses on the school servants on Christmas Day. The servants are an extremely heterogeneous group in terms of age and origin: Vico is a recovering alcoholic kicked out by his family, Nicola an ex-con, Tino a madman, and Salvatore an analphabetic homeless man. Within the microcosm of the school, they represent an exploited and marginalized social class; overworked by the priests, they are also constantly mocked and humiliated by the students. Even their shared sleeping quarters located next to the pigsty underline the almost animalistic conditions in which they live. As Italian film critic Sandro Bernardi explains, the servants' room resembles a psychiatric ward:

Their dormitory, next to the pigsty, full of religious writings and warnings, resembles the big rooms of confinement of the classical age. There, as recalled by Foucault, madness was mixed with all other forms of unreason, any other possible threat to the world order. (Bernardi 1978, p. 77)

Only on Christmas Day can they actually experience a certain degree of freedom, as the students are home for the holidays, and they are temporarily relieved of their working duties.

The dinner sequence is articulated in two parts, separated by a scene portraying a different storyline. The sequence opens with a shot of the 10 servants sitting around a table, looking expectantly in front of them. Above the dining table is a portrait of Pope Pius XII; next to the table, a nativity scene; and at the end of the room, an enormous fresco portraying Judgment Day. Before the impatient servants have the chance to begin eating, the school director starts a speech in which he explains that the priests will serve the servants, in what can be considered to be a role reversal. This, however, is more of an exercise in the Catholic virtues of humility and mercy than a demonstration of gratitude toward the servants. He also warns the servants that priests work all day everyday "without protesting, without going on strike" in a bid to shame the servants into not striking either. The school director also reminds the servants of all that the priests have done to help them, such as extracting them from dangerous situations, taking them in when no one else would, and rescuing them from extremely poor living conditions. As he continues with his reminder, the nuns proceed to tie napkins around the servants' necks, further underlining their inaptness at and incapability of taking care of themselves, as implied by the school director's patronizing, even humiliating words. Listening in silence, the servants show 
very little interest in the moralizing speech; however. Salvatore, in particular, makes a great show of eating while the director is still speaking. When one of the nuns castigates him, he simply grabs her and squeezes her bottom.

In the second part, chaos ensues. Ghiaccio is talking about the annunciation in rather blasphemous terms, alternating Italian with Latin formulas. Nicola puts on some music and invites one of the nuns to dance with him. Unexpectedly, she accepts, and the two waltz around the room, producing a rather surreal effect. At the same time, Tito, wearing a uniform and a helmet with antennas, and with mathematical formulas drawn on his face, walks solemnly across the room, pulling the long white tablecloth along with him. To the amusement of his companions, this causes everything to fall off the table and break. His journey terminates at the end of the room in front of the Judgment Day fresco. On the other side of the room, Nicola has pulled the nun down under the table. He is now on top of her, forcing himself on her. The sequence ends with a shot of the Judgment Day painting, the focus on the figure of God, who is showing His displeasure.

Toward whom this displeasure is directed is unclear. Is it toward the servants for their sacrilegious and disrespectful conduct, or is it toward those who have exploited their unfortunate condition, such as the priests and students? The answer becomes rather obvious if we consider the development of the plot and the impact on the protagonists as the film proceeds. Beato commits suicide after having an affair with a student; shocked by the event as well as by the school's intention to simply get rid of the servant's body to avoid a scandal, his companions finally decide to stand up for themselves. The non-violent revolt is led by Salvatore, who tries his best to organize and coordinate his peers. Despite his best efforts, however, the protest is quashed and he is fired.

\section{Conclusions}

In Nel nome del padre, Bellocchio takes issue with different aspects of pre-conciliar Catholicism as embodied by the microcosm of the Catholic boarding school and what lies immediately outside of it, that is, the peasant world. One of his targets is the superficial, formalistic quality of religious observance, which is especially evident in his portrayals of Pius XII's funeral broadcast and Fra' Matematicus's wake. In both cases, Bellocchio uses parody and satire in situations that would usually require the utmost respect and solemnity, highlighting how the students' and, what is worse, the priests' conduct is characterized by perfunctory adhesion to Catholicism rather than a committed and informed spiritual endeavor. Similarly, Bellocchio criticizes an uncritical religious affiliation as depicted in the episode of the "miraculous pear tree." While certainly more genuine and sincere, the peasants' faith is also problematic insofar as it is deeply embedded in superstitious, credulous practices detrimental to the development of the individual and society as a whole. Finally, through Marsilio's vision, Bellocchio also opposes the sexuophobic and repressive quality that characterizes education in the school by imagining a different outcome than the one presented in the exemplum-namely, the boy's forgiveness and consolation by the Virgin Mary. In other instances, however, Bellocchio does not limit himself to delivering criticism; he also suggests an alternative to the most problematic aspects connected to Catholicism. The placement of unorthodox elements in situations otherwise imbued with traditional Catholic elements serves to re-sacralize the former. Bellocchio is extremely critical of the exploitation of the weak by those in power. This is reflected in the episodes of Muscolo's crucifixion and the servants' dinner. In both cases, he associates Muscolo and the servants to Catholic symbols and paintings, giving them a sacred character.

Overall, Bellocchio's relationship with religion is peculiar. As pointed out by Brook (2009), the director's cinema constantly oscillates between the opposite poles of private and public, political and personal. Within this framework, the questions of personal freedom and self-determination occupy a prominent place. Clearly, the Catholic Church's hegemonic presence within Italy, even more salient during Bellocchio's formative years, and its unrelenting efforts to oversee not only the spiritual, but also frequently the cultural and political life of the population, constituted, for the director, unbearable interference. At the same time, however, and as already suggested by Fantuzzi (2005), beneath the 
director's often scathing, mocking tone lies an expression of regret for the loss of religious authenticity. In a way, Bellocchio does not appear to believe that an entirely secularized society would be a better option. In this sense, he is rather ambivalent and appears to be caught in between the desire for less and more religion: less repressive and censorial, and simultaneously more rigorous and sincere.

Religion remains essential to Bellocchio, as attested by the multiple functions Catholicism serves in Nel nome del padre. Indeed, Catholicism is simultaneously the critical target and tool to deliver the criticism. As already mentioned in the Introduction, Brook notes that Catholicism presents an irresistible lure to the director. She states: "Catholicism's iconography provides Bellocchio's cinema with a set of images without which his camera would lose its object. His films hint that Catholicism may remain deeply attractive in Italy's cinema, even where this is firmly disavowed" (Brook 2013, p. 399). I would argue, nevertheless, that Bellocchio's fascination goes beyond an interest for the Catholic "spectacle" and the creative potential of the Catholic iconographic repertoire. It is more than a mere aesthetic promise: it is rather-and very much so-a moral and even theological concern.

Funding: This research received no external funding.

Conflicts of Interest: The author declares no conflicts of interest.

\section{References}

Althusser, Louis. 2008. On Ideology. London: Verso.

Apostolos-Cappadona, Diana. 1994. Dictionary of Christian Art. New York: Continuum.

Aprà, Adriano. 2005. Marco Bellocchio: il cinema e i film. Venezia: Marsilio.

Bazin, André. 1997. Bazin at Work: Major Essays and Reviews from the Forties and Fifties. Edited by Bert Cardullo.

New York: Routledge.

Bellocchio, Marco, and Goffredo Fofi. 1971. Nel nome del padre. Bologna: Cappelli.

Bellocchio, Marco, and Nicoletta Zalaffi. 1973. Interview with Marco Bellocchio. Sight and Sound 42: 197-99, 231.

Benini, Stefania. 2015. Pasolini. The Sacred Flesh. Toronto: University of Toronto Press.

Bernardi, Sandro. 1978. Marco Bellocchio. Firenze: La Nuova Italia.

Betti, Giorgio. 2010. Il pensiero e la dinamite: Riflessioni su alcuni film di Marco Bellocchio. Bobbio: Pontegobbo.

Bondanella, Peter. 2009. A History of Italian Cinema. New York: Continuum International Pub. Group.

Brook, Clodagh. 2007. The Oneiric in the Cinema of Marco Bellocchio. Italica: Bulletin of the American Association of Teachers of Italian 84: 479-94.

Brook, Clodagh. 2009. Marco Bellocchio. The Cinematic I in the Political Sphere. Toronto: University of Toronto Press.

Brook, Clodagh. 2013. The Spectacle of the Unseen: Marco Bellocchio and Lure of the Catholic Church. Italian Studies 68: 399-410. [CrossRef]

Calabrò, Roberto. 2004. La musica nel cinema di Marco Bellocchio. In Nè padri nè madri. Il cinema di Marco Bellocchio. Edited by Alberto Achilli and Gianfranco Casadio. Ravenna: Comune di Ravenna, pp. 29-64.

Carroll, Micheal. 1992. Madonnas that Maim: Popular Catholicism in Italy Since the Fifteenth Century. Baltimore: Johns Hopkins University Press.

Carroll, Margaret D. 1993. "In the Name of God and Profit": Jan van Eyck's Arnolfini Portrait. Representations 44: 96-132. [CrossRef]

Deacy, Christopher. 2008. The Pedagogical Challenges of Finding Christ Figures in Film. In Teaching Religion and Film. Edited by Gregory J. Watkins. Oxford: Oxford University Press, pp. 129-40.

Fantuzzi, Virgilio. 2005. Marco Bellocchio: Tra sacralità e dissacrazione. In Marco Bellocchio: Il Cinema e i Film. Edited by Adriano Aprà. Venezia: Marsilio, pp. 70-91.

Ginsborg, Paul. 1990. A History of Contemporary Italy: Society and Politics, 1943-1988. London: Penguin Books.

Harbison, Craig. 1990. Sexuality and Social Standing in Jan van Eyck's Arnolfini Double Portrait. Renaissance Quarterly 43: 249-91. [CrossRef]

Italia Taglia. 2018. “Nel nome del padre," Italia Taglia. Available online: http:/ / www.italiataglia.it/ (accessed on 20 August 2018).

Jacobs, Steven. 2012. Framing Pictures. Film and the Visual Arts. Edinburgh: Edinburgh University Press.

Kozlovich, Anton Karl. 2004. The Structural Characteristics of the Cinematic Christ-figure. Journal of Religion and Popular Culture 8. [CrossRef] 
Kroger, Joseph, and Patriizia Granziera. 2012. Aztec Goddesses and Christian Madonnas: Images of the Divine Feminine in Mexico. Farnham: Ashgate.

Lyons, John D. 1989. Exemplum: The Rhetoric of Example in Early Modern France and Italy. Princeton: Princeton University Press.

Maggi, Armando. 2009. The Resurrection of the Body. Pier Paolo Pasolini from Saint Paul to Sade. Chicago: University of Chicago Press.

Magli, Ida. 1987. La Madonna. Milano: Rizzoli.

Marenbon, John. 1997. The Philosophy of Peter Abelard. Cambridge: Cambridge University Press.

Moliterno, Gino. 2009. The A to Z of Italian Cinema. Lanham: The Scarecrow Press.

Morandini, Morando. 1997. Italy: Auteurs and After. In The Oxford History of World Cinema. Edited by Geoffrey Nowell-Smith. Oxford: Oxford University Press, pp. 586-95.

Morgoglione, Claudia. 2006. Solo la passione può salvarci l'ultima provocazione di Bellocchio. La Repubblica. Roma. Available online: http:/ / www.repubblica.it/2006/04/sezioni/spettacoli_e_cultura/regista-di-matrimoni/ regista-di-matrimoni/regista-di-matrimoni.html?ref=search (accessed on 16 July 2018).

O'Malley, John W. 2010. A History of the Popes: From Peter to the Present. Lanham: Sheed \& Ward.

Panofsky, Erwin. 1934. Jan van Eyck's “Arnolfini” portrait. The Burlington Magazine for Connoisseurs 64: 117-19, 122-27.

Pasolini, Pier Paolo. 1998. I romanzi. Edited by Walter Siti. Milan: Mondadori.

Pasolini, Pier Paolo. 1999a. Per il cinema. Edited by Walter Siti. Milan: Mondadori.

Pasolini, Pier Paolo. 1999b. Il sogno del centauro. Incontri con Jean Duflot [1969-1975]. In Saggi sulla politica e sulla società. Tomo I. Edited by Walter Siti. Milan: Mondadori, pp. 1401-50.

Pasolini, Pier Paolo, and Jon Halliday. 1992. Pasolini su Pasolini. Conversazioni con Jon Halliday. Parma: Guanda.

Pelaja, Margherita, and Lucetta Scaraffia. 2008. Due in una Carne: Chiesa e Sessualità nella Storia. Roma: Laterza.

Pollard, John. 2014. The Papacy in the Age of Totalitarism, 1914-1958. Oxford: Oxford University Press.

Rohdie, Sam. 1995. The Passion of Pier Paolo Pasolini. London: BFI Publishing.

Ryan-Scheutz, Colleen. 2007. Sex, the Self, and the Sacred: Women in the Cinema of Pier Paolo Pasolini. Toronto: University of Toronto Press.

Sànchez, Josè M. 2002. Pius XII and the Holocaust: Understanding the Controversy. Washington, DC: The Catholic University of America Press.

Sax, Boria. 2001. The Mythical Zoo: An Encyclopedia of Animals in World Myth, Legend, and Literature. Santa Barbara: ABC-CLIO.

Sitney, Paul Adams. 2013. Vital Crises in Italian Cinema: Iconography, Stylistics, Politics. Oxford: Oxford University Press. First published 1995.

Subini, Tomaso. 2009. Pier Paolo Pasolini. La ricotta. Torino: Lindau.

Wright, Melanie J. 2007. Religion and Film: An Introduction. London: I.B. Tauris.

(C) 2018 by the author. Licensee MDPI, Basel, Switzerland. This article is an open access article distributed under the terms and conditions of the Creative Commons Attribution (CC BY) license (http:/ / creativecommons.org/licenses/by/4.0/). 